\title{
GAME ONLINE DUEL MATEMATIKA BERBASIS WEB
}

\author{
Masnur $^{1}$, Tri Hariadi Purnomo ${ }^{2}$ \\ ${ }^{1,2}$ Program Studi Teknik Informatika, Universitas Muhammadiyah Parepare \\ masnur2010@gmail.com
}

Corespondent Author : Masnur (masnur2010@gmail.com)

\begin{abstract}
Mathematics is a science that is very useful in everyday life. Mathematics lessons can be applied in various ways in everyday life. Hone skills in arithmetic can be done through interactive games such as games or games that are digital. This kind of game or game aims to provide education and a spirit of competition, especially in mathematics, by competing with other people to hone skills and speed in answering questions. A webbased math duel game made with HTML5, CSS3, PHP, and JavaScript technology. In this game, players can duel in Realtime with opponents in answering questions correctly and accurately by using a matching system according to the player's ranking. This Math Duel Web Game also has three types of games so that players have more playing options.
\end{abstract}

Keywords: Online Games, Mathematics, Duel, Web.

ABSTRAK - Matematika merupakan salah satu ilmu yang sangat bermanfaat dalam kehidupan sehari-hari. Pelajaran Matematika bisa diaplikasikan dalam berbagai macam hal di kehidupan seharihari. Mengasah kemampuan dalam hitung-menghitung dapat dilakukan melalui permainan interaktif seperti Game atau permainan yang bersifat digital. Game atau permainan sejenis ini bertujuan untuk memberikan edukasi dan semangat berkompetisi terutama dalam ilmu matematika, dengan cara melakukan tanding dengan orang lain untuk mengasah kemampuan dan kecepatan menjawab soal. Game duel matematika berbasis web dibuat dengan teknologi HTML5 , CSS3, PHP, dan JavaScript. Dalam Game ini pemain bisa berduel secara Realtime bersama lawan dalam menjawab soal-soal secara benar dan tepat dengan menggunakan sistem matching menurut peringkat pemain. Web Game Duel Matematika ini juga memiliki tiga jenis permainan agar pemain memiliki opsi bermain yang lebih banyak.

Kata Kunci : Game Online, Matematika, Duel, Web.

\section{PENDAHULUAN}

Matematika merupakan salah satu ilmu yang sangat bermanfaat dalam kehidupan sehari-hari. Pelajaran Matematika bisa diaplikasikan dalam berbagai macam hal di kehidupan sehari-hari. Misalnya saja dalam transaksi perdagangan, dalam kegiatan pertukangan, dalam berbagai macam pengukuran, dan masih banyak lagi hal lainnya yang berhubungan dengan ilmu Matematika.

Mengasah kemampuan dalam ilmu matematika dianggap penting, karena setiap kegiatan yang dilakukan di lingkungan masyarakat tidak pernah jauh dari hal hitungmenghitung, serta banyaknya perlombaan olimpiade matematika mendorong semangat kompetisi dalam berlomba-lomba mempelajari ilmu matematika.

Dengan alasan tersebut penulis memutuskan untuk merancang Game Online Duel Matematika Berbasis Web. Dimana aplikasi ini diharapkan dapat menumbuhkan semangat berkompetisi dan mempelajari matematika lebih banyak. Pada penelitian ini penulis juga banyak menggunakan artikel yang dijadikan bahan literasi penulis.[1][2]

\section{METODE PENELITIAN}

\section{Tempat dan Waktu Penelitian}

Laboratorium Teknik Informatika yang beralamat di Jalan Jendral Ahmad Yani km. 6, Bukit Harapan, Soreang, Kota Parepare, Sulawesi Selatan 91112, UM Parepare gedung F lantai 3, dan waktu penelitian ini akan dilaksanakan selama kurang lebih \pm 2 bulan pada tahun 2019.

\section{Jenis Penelitian}

Penulis mengadakan studi literatur dengan membaca dan mempelajari buku-buku dan refrensi dari website atau situs-situs yang berhubungan dengan tugas akhir serta mempelajari teori-teori dan game berbasis web lainnya.

\section{Metode Pengumpulan Data}

Metode yang digunakan oleh penulis untuk pengumpulan data dalam peneletian ini yaitu dengan menggunakan beberapa metode antara lain :

1. Studi Pustaka

Mencari teori dan informasi yang berhubungan dengan topik yang akan dibuat. Pencarian teori dan informasi akan dicari melalui buku-buku, internet, dan hasil penelitian maupun karya ilmiah.

2. Analisis web sejenis

Mencari informasi tentang web atau game dengan topik yang sama dan membandingkannya.

3. Bahan penelitian

Bahan penelitian berupa buku-buku, web dan game yang memiliki topik yang sama dengan tema penelitian. 


\section{Tahapan Penelitian}

1. Persiapan Penelitian

Pada tahapan ini peneliti melakukan persiapan penelitian. Persiapan penelitian yang dimaksud adalah menyiapkan buku-buku, artikel-artikel tentang topik penelitian serta software yang digunakan selama penelitian.

2. Pengumpulan Data

Pada tahap ini penelitianmengumpulkan informasi tentang topik dari tugas akhir melalui bukubuku dan web sejenis.

3. Analisis

Pada tahap analisis, peneliti melakukan analisa terhadap sistem yang di terapkan sekarang berdasarkan kemudian merumuskan masalah yang menjadi pokok penelitian sehingga dapat dibuat alternatif pemecahan masalah.

4. Perancangan

Peneliti kemudian merancang aplikasi yang ingin dibuat berdasarkan alternatif pemecahan masalah.

5. Pengujian

Setelah melakukan perancangan, peneliti kemudian menguji hasil perancangan yang telah dibuat.

6. Implementasi

Setelah pada perancangan tidak terdapat kekurangan maka aplikasi siap untuk di gunakan oleh user.

\section{HASIL DAN PEMBAHASAN}

Analisis Aliran Data dengan UML

1. Use Case Diagram

a. Admin

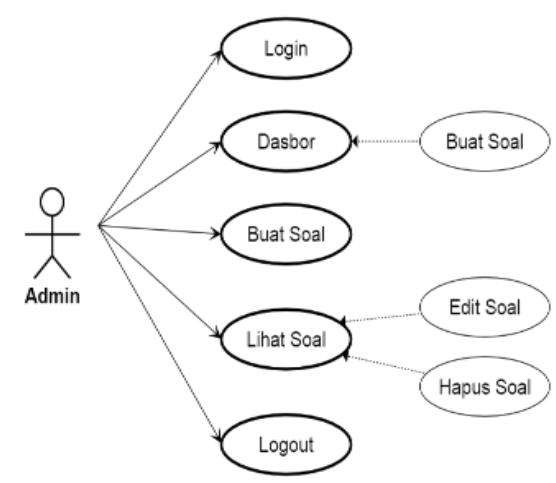

Gambar 1. Use Case Diagram Admin

b. User

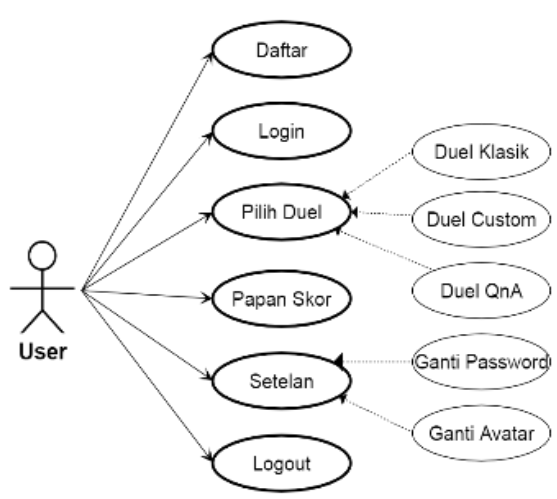

Gambar 2. Use Case Diagram Player

2. Activity Diagram

a. Admin

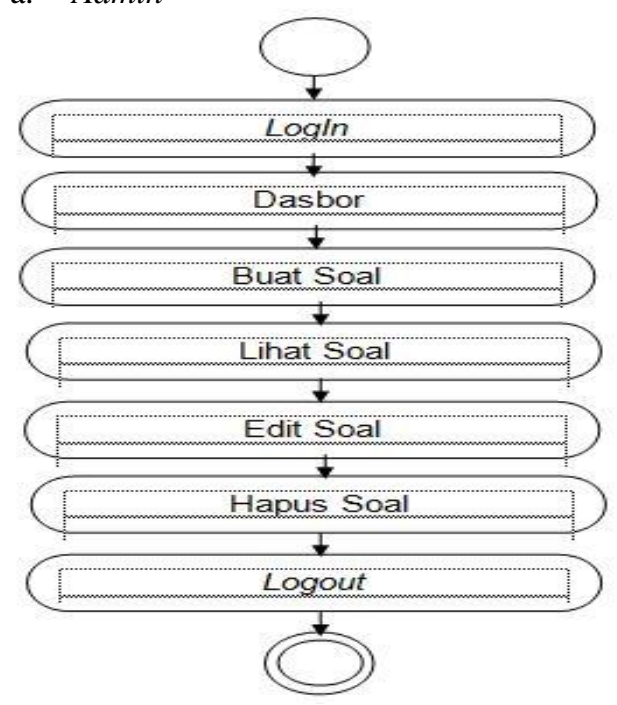

Gambar 3. Activity Diagram Admin

b. User

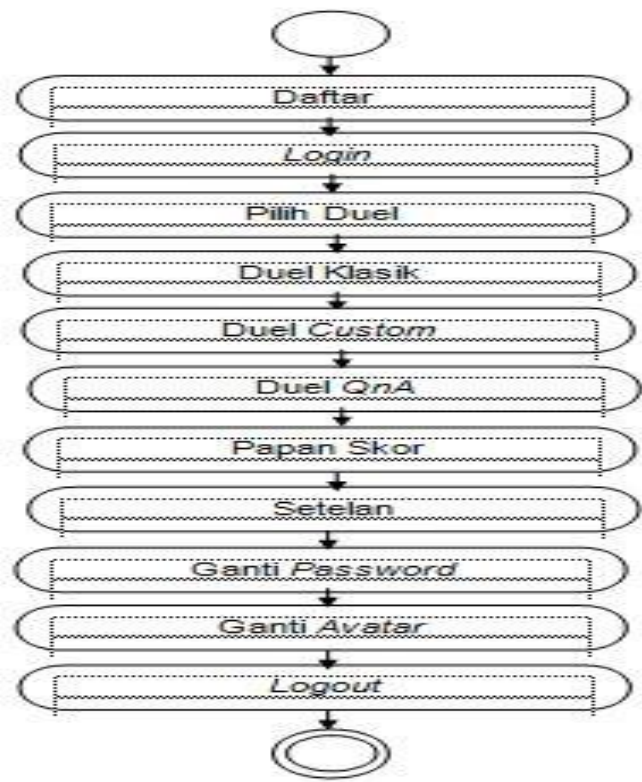

Gambar 4. Activity Diagram Player

\section{Sequence Diagram}

a. Diagram Sequence Admin 


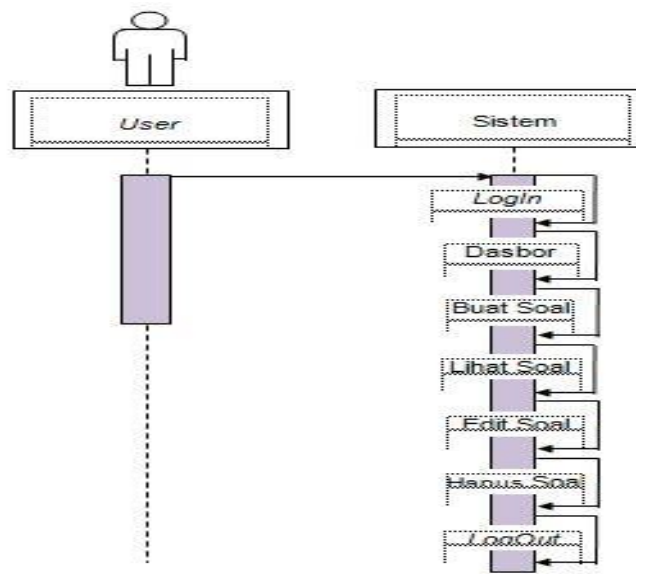

Gambar 5. Sequence Diagram Admin

b. Diagram Sequence User

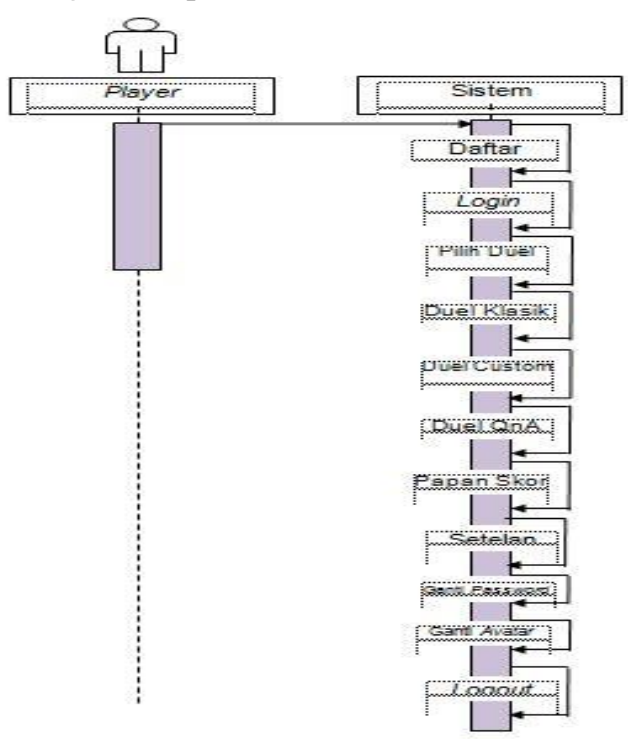

Gambar 6. Sequence Diagram Player

\section{DFD (Data Flow Diagram)}

DFD (Data Flow Diagram) adalah suatu langkah atau metode untuk membuat sebuah perancangan sistem yang mana berorientasi pada alur data yang bergerak kesebuah sistem lainnya.

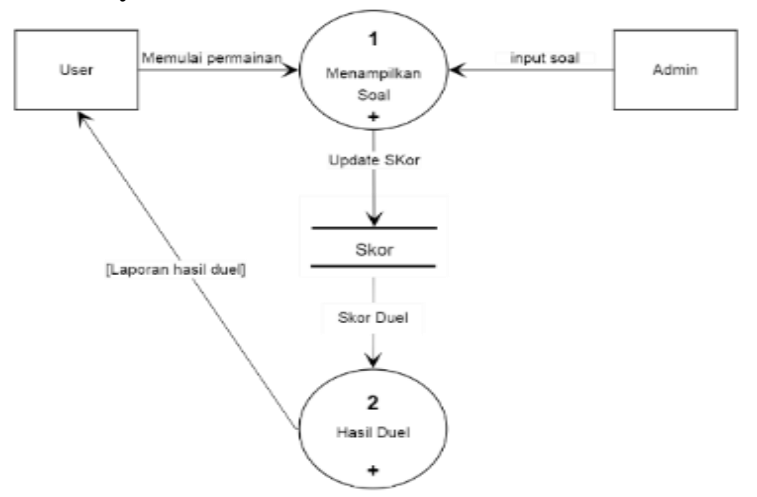

Gambar 7. Data Flow Diagram

\section{Class Diagram}

Class diagram adalah visual dari struktur sistem program pada jenis-jenis yang di bentuk. Class diagram merupakan alur jalannya database pada sebuah sistem.

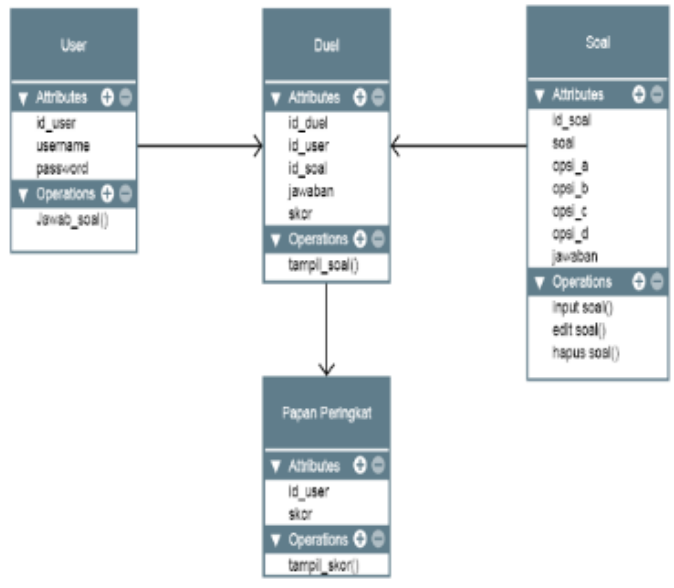

Gambar 8. Class Diagram

\section{Detail Aplikasi}

1. Halaman Login

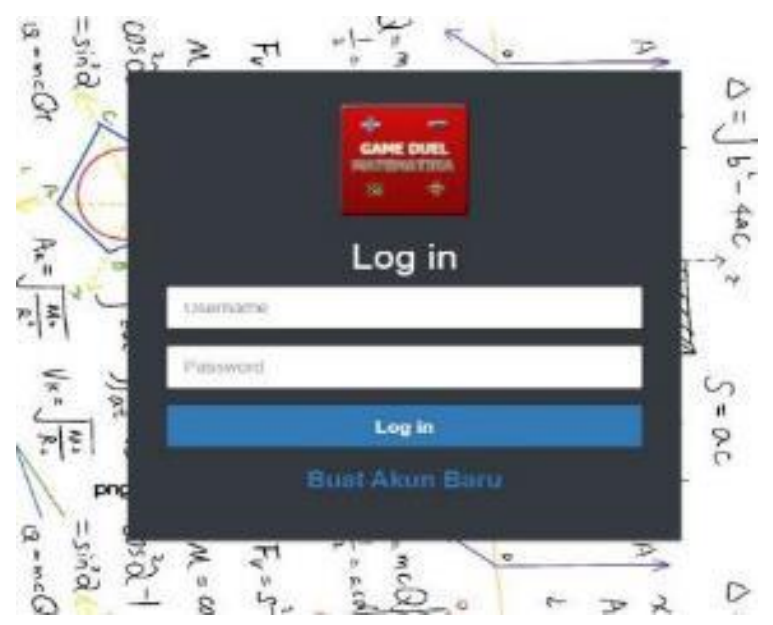

Gambar 9. Halaman Login

2. Halaman Pilih Duel

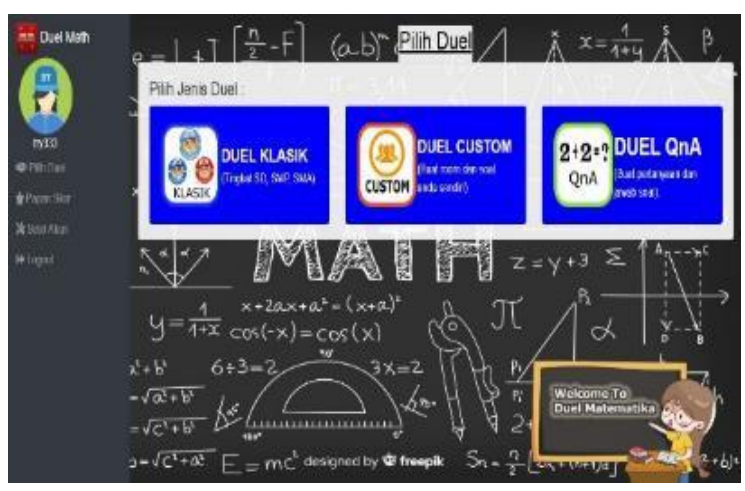

Gambar 10. Halaman Pilih Duel

3. Halaman Duel Klasik 


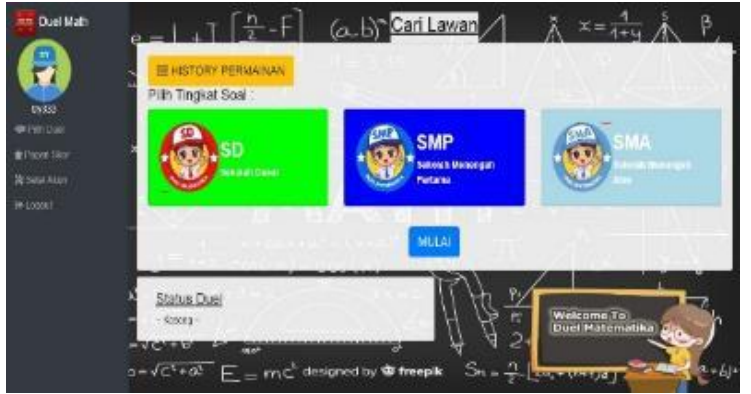

Gambar 11. Halaman Cari Lawan

4. Halaman Bertemu Lawan

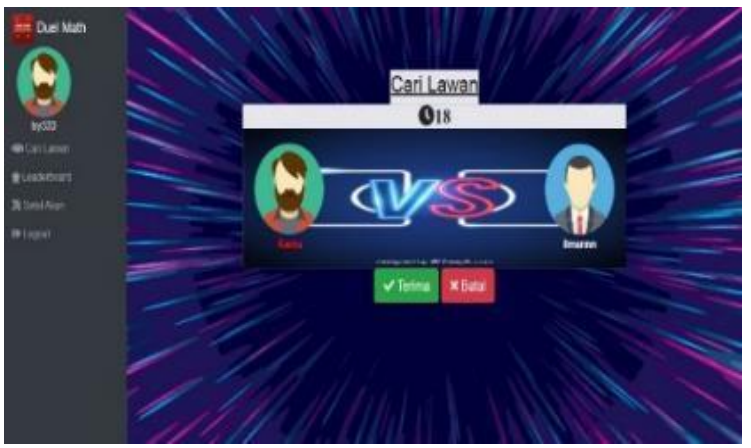

Gambar 12. Halaman Bertemu Lawan

5. Halaman Berduel

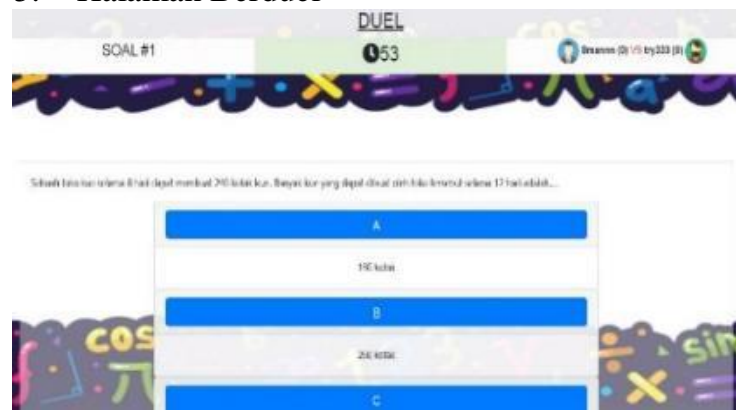

Gambar 13. Halaman Berduel

6. Halaman Hasil Duel

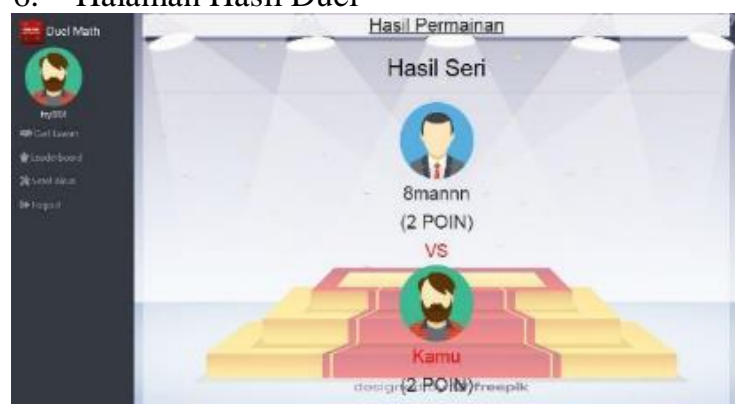

Gambar 14. Halaman Hasil Duel

7. Halaman Riwayat Permainan

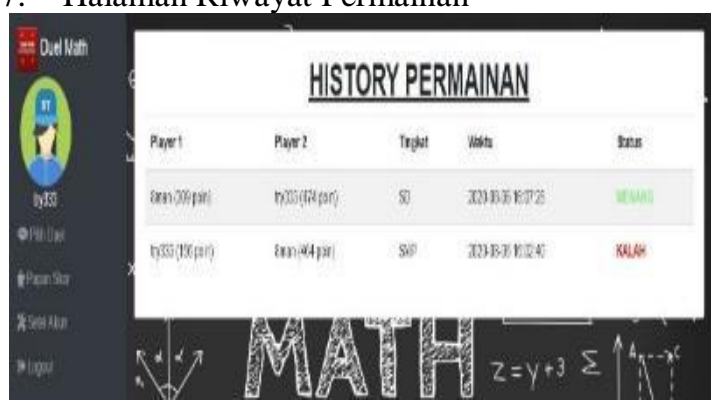

Gambar 15. Halaman History Permainan

8. Halaman Papan Skor

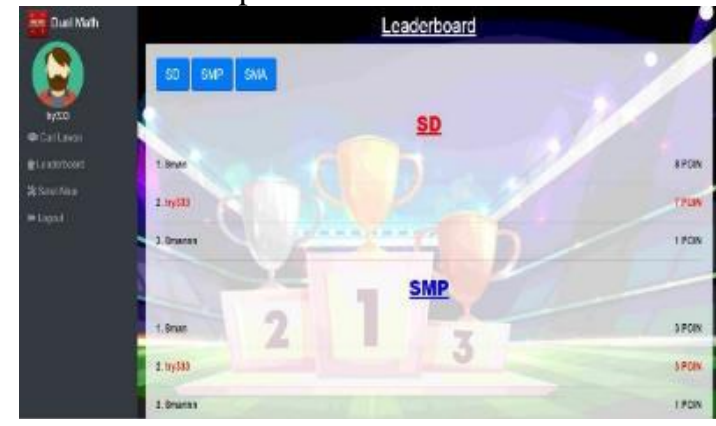

Gambar 16. Halaman Papan Skor

\section{Implementasi}

Implementasi sistem merupakan tahap penerapan dari suatu teknologi yang didesain untuk siap dioperasikan. Tahap ini merupakan terjemahan perancangan dari bab hasil analisis sebelumnya dalam suatu bahasa pemrograman.

Bahasa pemrograman yang digunakan untuk membuat aplikasi game duel matematika ini adalah PHP dan Javascript.

1. Kebutuhan Perangkat Keras

Tabel 1. Kebutuhan Perangkat Keras

\begin{tabular}{|l|l|}
\hline \multicolumn{1}{|c|}{ Jenis } & \multicolumn{1}{c|}{ Spesifikasi } \\
\hline Notebook/Komputer & Acer \\
\hline Processor & $\begin{array}{l}\text { Pentium(R) Dual-Core CPU, up } \\
\text { to } 2.2 \mathrm{GHz}\end{array}$ \\
\hline Memory & $1 \mathrm{~GB}$ RAM \\
\hline Harddisk & $160 \mathrm{~GB}$ \\
\hline
\end{tabular}

2. Kebutuhan Perangkat Lunak

Tabel 2. Kebutuhan Perangkat Lunak

\begin{tabular}{|c|c|}
\hline Jenis & Spesifikasi \\
\hline Sistem Operasi & Windows 7 Ultimate, x32-bit \\
\hline
\end{tabular}

\section{Pengujian Sistem}

\section{Black-Box}

Tabel 3. Black Box Halaman Daftar User

\begin{tabular}{|c|c|c|}
\hline Test Faktor & Hasil & Kesimpulan \\
\hline $\begin{array}{l}\text { Halaman daftar User, } \\
\text { masukkan Username } \\
\text { yang belum terdaftar } \\
\text { dan Password. }\end{array}$ & $\checkmark$ & $\begin{array}{c}\text { Username yang } \\
\text { dimasukkan harus } \\
\text { belum digunakan oleh } \\
\text { User lain }\end{array}$ \\
\hline \multicolumn{3}{|c|}{ Screen Shoot } \\
\hline 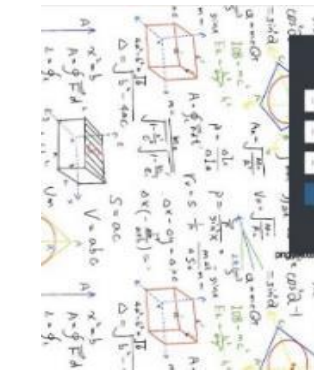 & $=\sin$ & 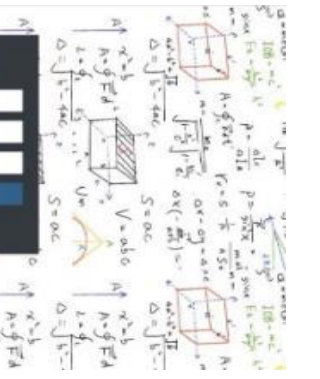 \\
\hline
\end{tabular}


Tabel 42. Black Box Halaman Cari Lawan

\begin{tabular}{|c|c|c|}
\hline Test Faktor & Hasil & Kesimpulan \\
\hline $\begin{array}{c}\text { Halaman cari lawan, } \\
\text { pilih tingkat soal dan } \\
\text { tekan tombol mulai. }\end{array}$ & $\checkmark$ & $\begin{array}{c}\text { Tampilan } \\
\text { halaman cari } \\
\text { lawan. }\end{array}$ \\
\hline \multicolumn{3}{|c|}{ Screen Shoot } \\
\hline
\end{tabular}

Tabel 53. Black Box Halaman Bertemu Lawan

\begin{tabular}{|c|c|c|}
\hline $\begin{array}{c}\text { Test Faktor } \\
\text { Halaman ketika user } \\
\text { bertemu player lain untuk } \\
\text { berduel. }\end{array}$ & $\checkmark$ & $\begin{array}{c}\text { Tampilan } \\
\text { halaman, ketika } \\
\text { bertemu lawan. }\end{array}$ \\
\hline \multicolumn{3}{|c|}{ Screen Shoot } \\
\hline
\end{tabular}

Tabel 64. Black Box Halaman Berduel

\begin{tabular}{|c|c|c|}
\hline Test Faktor & Hasil & Kesimpulan \\
\hline $\begin{array}{c}\text { Halaman ketika } \\
\text { pemain setuju } \\
\text { berduel, dan } \\
\text { menampilkan soal } \\
\text { dan pilihan } \\
\text { jawaban. }\end{array}$ & $\checkmark$ & $\begin{array}{c}\text { Menampilkan soal, } \\
\text { pilihan jawaban, } \\
\text { waktu, dan skor } \\
\text { sementara. }\end{array}$ \\
\hline \multicolumn{3}{|c|}{ Screen Shoot } \\
\hline \\
\hline
\end{tabular}

Tabel 75. Black Box Pilihan Jawaban Salah

\begin{tabular}{|c|c|c|}
\hline Test Faktor & Hasil & Kesimpulan \\
\hline
\end{tabular}

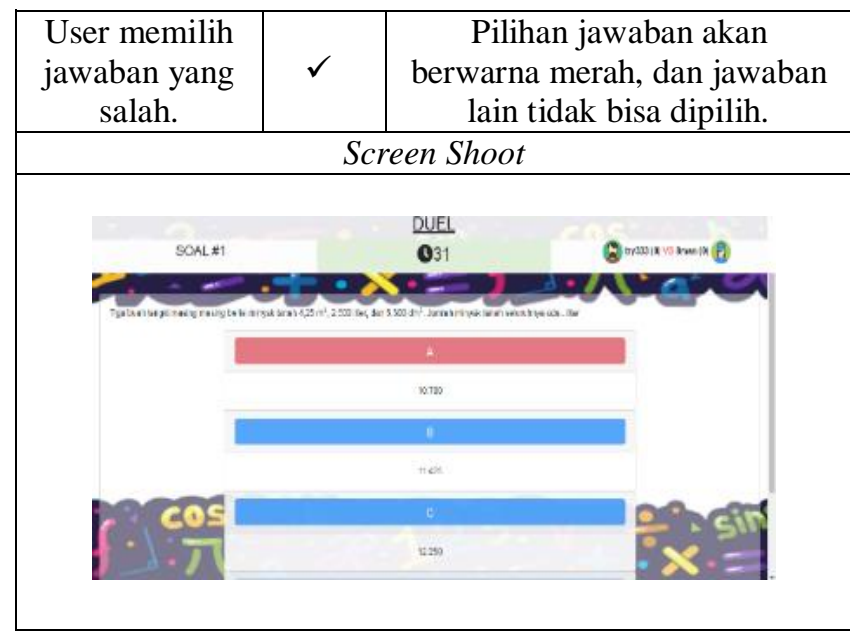

Tabel 86. Black Box Pilihan Jawaban Benar

\begin{tabular}{|c|c|c|}
\hline $\begin{array}{c}\text { Test Faktor } \\
\text { jawaban yang } \\
\text { benar. }\end{array}$ & Hasil & $\begin{array}{c}\text { Pesimpulan jawaban akan } \\
\text { berwarna hijau, dan lanjut ke } \\
\text { soal berikutnya. }\end{array}$ \\
\hline & Screen Shoot \\
\hline & $\cdots$ \\
\hline
\end{tabular}

Tabel 97. Black box Hasil Duel

\begin{tabular}{|c|c|c|}
\hline $\begin{array}{c}\text { Test Faktor } \\
\begin{array}{c}\text { Halaman saat duel } \\
\text { selesai dan } \\
\text { dampilkan hasil }\end{array}\end{array}$ & $\checkmark$ & $\begin{array}{c}\text { Menampilkan hasil } \\
\text { duel, menang, kalah, } \\
\text { atau seri, dan skor } \\
\text { akhir. }\end{array}$ \\
\hline \multicolumn{2}{|c|}{ Screen Shoot } \\
\hline Hasil Permanan \\
\hline
\end{tabular}

Tabel 108. Black box Halaman Dasbor Admin

\begin{tabular}{|c|c|c|}
\hline Test Faktor & Hasil & Kesimpulan \\
\hline $\begin{array}{l}\text { Halaman dasbor } \\
\text { admin, halaman } \\
\text { awal admin jika } \\
\text { login berhasil. }\end{array}$ & $\checkmark$ & $\begin{array}{c}\text { Tampilan awal Dasbor } \\
\text { Admin, menampilkan jumlah } \\
\text { User, jumlah soal, dan } \\
\text { riwayat duel. }\end{array}$ \\
\hline \multicolumn{3}{|c|}{ Screen Shoot } \\
\hline
\end{tabular}




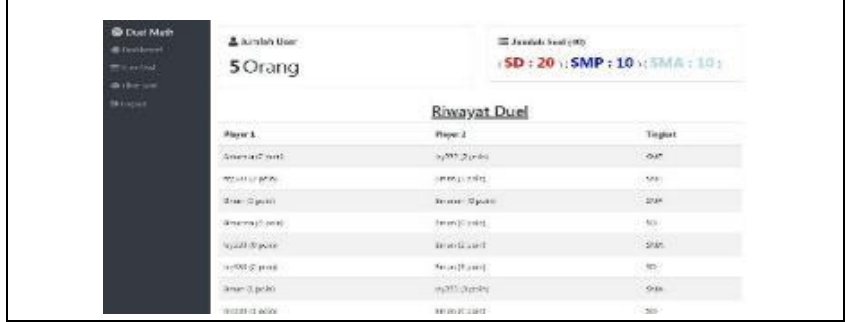

Tabel 119. Black box Halaman Buat Soal

\begin{tabular}{|c|c|c|}
\hline $\begin{array}{c}\text { Test Faktor } \\
\begin{array}{c}\text { Jika admin } \\
\text { mekan sidebar } \\
\text { buat soal. }\end{array}\end{array}$ & $\checkmark$ & $\begin{array}{c}\text { Tampilan halaman buat } \\
\text { soal, menampilkan form } \\
\text { input soal dan pilihan } \\
\text { jawaban. }\end{array}$ \\
\hline \multicolumn{2}{|c|}{ Screen Shoot } \\
\hline \multicolumn{2}{|c|}{} \\
\hline
\end{tabular}

Tabel 1210. Black box Soal Halaman Lihat Soal

\begin{tabular}{|c|c|c|}
\hline $\begin{array}{c}\text { Test Faktor } \\
\text { Jika admin } \\
\text { menan sidebar } \\
\text { lihat soal. }\end{array}$ & $\checkmark$ & $\begin{array}{c}\text { Tampilan halaman lihat soal, } \\
\text { menampilkan soal, tombol } \\
\text { edit soal, dan hapus soal. }\end{array}$ \\
\hline \multicolumn{3}{|c|}{ Screen Shoot } \\
\hline \multicolumn{2}{|c|}{ UHAT SOAL } \\
\hline & \\
\hline &
\end{tabular}

Tabel 1311. Black box Halaman Edit Soal

\begin{tabular}{|c|c|c|}
\hline $\begin{array}{c}\text { Test Faktor } \\
\text { Jika } \text { admin } \\
\text { edit soal. }\end{array}$ & Hasil & Kesimpulan \\
\hline \multicolumn{2}{|c|}{ Screen Shoot } \\
\hline
\end{tabular}

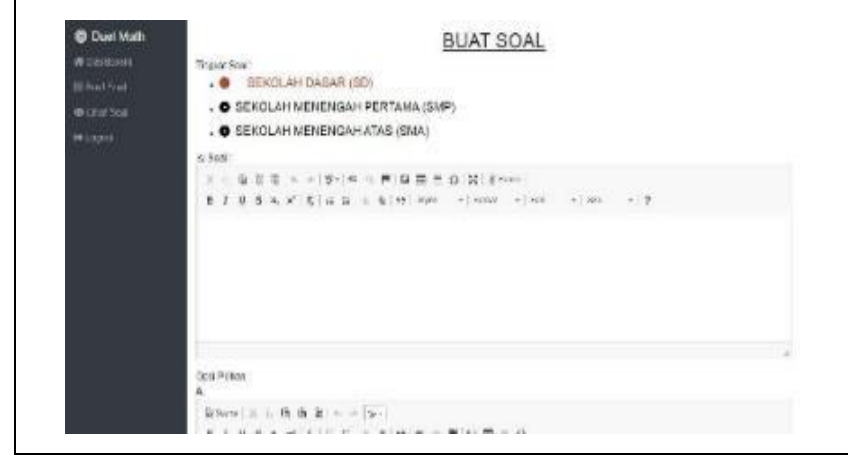

Tabel 1412. Black box Buat Room

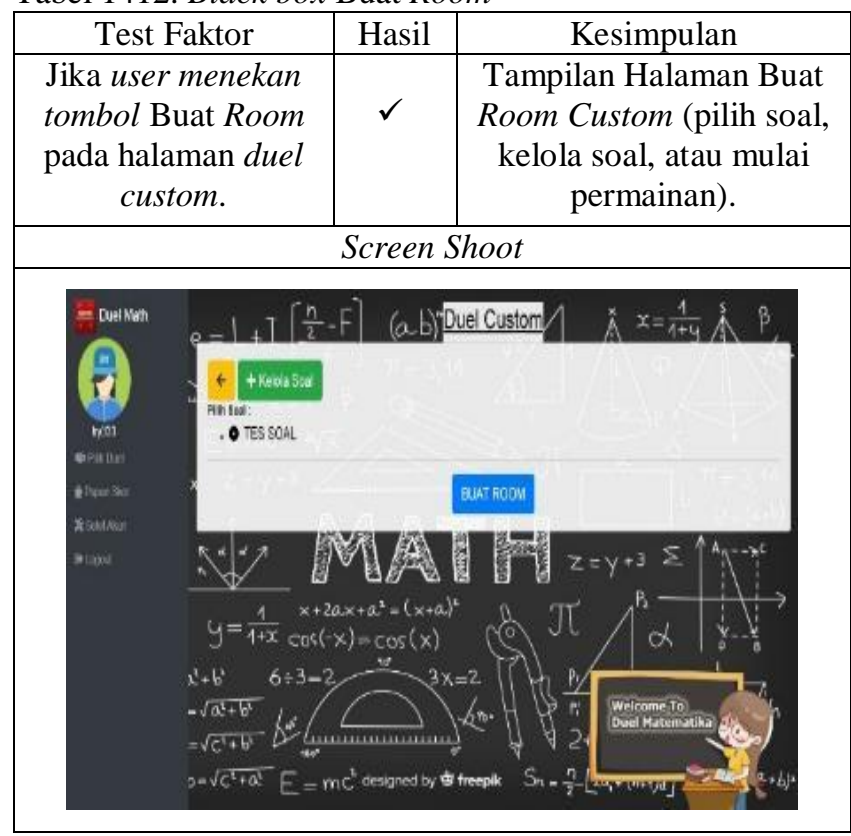

2. White Box

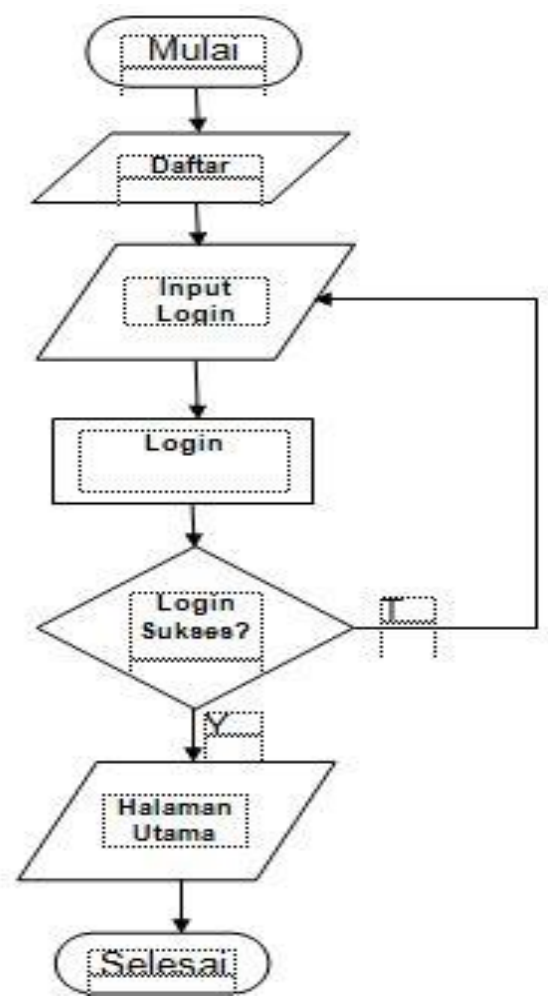


Gambar 18. Flowchart Login User

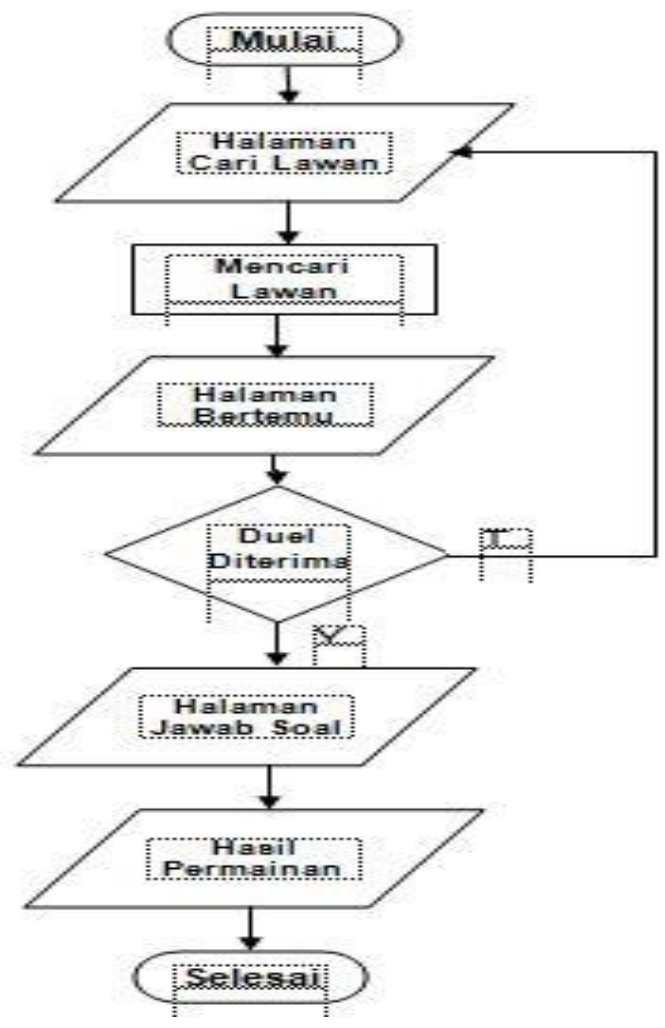

Gambar 19. Flowchart Berduel

\section{PENUTUP}

\section{A. Kesimpulan}

Kesimpulan dari hasil penelitian dan pembahasan dari pembuatan Game Online Duel Matematika Berbasis WEB antara lain :

1. Web game duel matematika memiliki dua hak akses yaitu user sebagai pemain dan Admin bertugas untuk menambah, mengedit dan menghapus soal.

2. Web game duel matematika memiliki 3 jenis duel yang berbeda-beda, yaitu Duel Klasik (tingkat SD, SMP, SMA), Duel Custom, Duel QnA.

3. Web game duel matematika meiliki Admin yang dapat menginput soal, edit soal, dan hapus soal.

4. Sistem penentuan lawan duel pada aplikasi ini menggunakan 2 (dua) parameter, yaitu waktu dan selisih skor di papan peringkat.

\section{B. Saran}

Setelah selesai melaksanakan penelitian ini, maka penulis bisa memberikan saran demi perbaikan di masa mendatang yaitu:

1. Penelitian selanjutnya perlu menambahkan jumlah mata pelajaran, bukan hanya mata pelajaran matematika saja, serta diharapkan sudah memiliki pembahasan soal.
2. Diharapkan pada penelitian selanjutnya, agar menambahkan catatan atau progres perkembangan jumlah soal benar dan salah, serta kecepatan menjawab pemain saat selesai berduel.

3. Game yang penulis buat masih berbasis web, diharapkan dalam pengembangan selanjutnya dapat dikembangkan dengan desain yang lebih menarik dan memudahkan User, serta dapat dibuat versi aplikasi Android ataupun $i O S$.

\section{DAFTAR PUSTAKA}

[1] M. Masnur and Difla, "SISTEM INFORMASI PENYEDIA LOWONGAN KERJA BERBASIS WEB,” 2021. doi: 10.31850/JSILOG.V1I2.813.

[2] M. Marlina, M. Masnur, and M. Dirga.F, "Aplikasi E-Learning Siswa Smk Berbasis Web," J. Sintaks Log., vol. 1, no. 1, pp. 8-17, Jan. 2021, doi: 10.31850/JSILOG.V1I1.672.

[3] Agustinus Nilwan (2008). Pemrograman Animasi dan Game professional. Elex Media komputindo. Jakarta.

[4] Bunafit Nugroho. (2008). Aplikasi Pemrograman Web Dinamis Dengan PHP dan MySQL. Gava Media. Yogyakarta.

[5] Firman A, Wowor HF, \& Najoan X. 2016. Sistem Informasi Perpustakaan Online Berbasis Web. Ejournal Teknik Elektro dan Komputer. 5(2): 29-36.

[6] Kuswardayan,I, Nikensasi, P, Sunaryo, D. 2012. Rancang Bangun Permainan Edukasi Matematika dan Fisika dengan Memanfaatkan Accelerometer dan Physics Engine Box $2 d$ pada Android. Jurnal ITS. (Hal. 255-260).

[7] Kadir, Abdul. 2013. Java Script \& Jquery. Penerbit:Andi. Yogyakarta.

[8] Martono, Kurniawan Teguh. 2015. Pengembangan Game dengan Menggunakan Game Engine Game Maker, Indonesia: Jurnal Sistem Komputer (JSISKOM), Mei 2015, vol 5 No 1, ISSN: 20874865, e-ISSN: 2252-3456.

[9] Nugroho ,Adi. 2009. Rekayasa Perangkat Lunak Menggunakan UML dan Java. Andi Offset.Yogyakarta.

[10] Priyanto Hidayatullah, Jauhari Khairul Kawistara. 2017. Pemrograman WEB Edisi Revisi. Bandung: INFORMATIKA

[11] Purba, Joe. Pengertian Dasar Dan Simbol Flowchart, (Online).https://www.academia.edu/6912277/PENG ERTIAN_DASAR_DAN_SIMBOL_FLOWCHART (diakses pada tanggal 11 Juli 2019 jam 05:57 WITA).

[12] Sholiq. 2006. Pemodelan Sistem Informasi Berorientasi Objek dengan UML.Graha Ilmu. Yogyakarta.

[13] Suherman, Erman dkk. 2003. Strategi Pembelajaran Matematika Kontemporer. Bandung: PT Remaja Rosdakarya. 
[14] Sussi, Munadi R, Prasojoe RR, Fitriyati N, Shihab KM. 2019. Pembuatan Game Online BoMCleaN sebagai Media Pembelajaran Kebersihan Lingkungan. JEPIN (Jurnal Edukasi dan Penelitian Informatika). Vol 5 No 1: Hal 113-118.

[15] Y. Kustiyahningsih, D. Rosa, Pemrograman Basis Data Berbasis WEB Menggunakan PHP dan Mysql, Yogyakarta: Graha Ilmu, 2011. 